\title{
Bulnesia sarmientoi Wood Oil
}

National Cancer Institute

\section{Source}

National Cancer Institute. Bulnesia sarmientoi Wood Oil. NCI Thesaurus. Code C72187.

The essential oil extracted from the heartwood of Bulnesia sarmientoi. Bulnesia sarmientoi wood oil is used for its aromatic properties. 